\title{
The angiotensin-I converting enzyme (ACE) gene I/D polymorphism and ACE levels in Pima Indians
}

Carole A Foy, Lynn J McCormack, William C Knowler, Jennifer H Barrett, Andrew Catto, Peter J Grant

\begin{abstract}
An insertion/deletion (I/D) polymorphism of the angiotensin converting enzyme (ACE) gene is associated with plasma ACE levels in white populations. The occurrence of the I/D polymorphism and relationship to ACE levels was examined in a Pima Indian group $(n=305)$. The frequency of the $D$ allele was lower in Pimas than whites $(0.29 v 0.52$ respectively). ACE levels were significantly associated with genotype in both groups $(p=0 \cdot 0001)$, which accounted for $6.5 \%$ of the variation in ACE levels in Pimas and $18 \%$ in whites. The association of the I/D polymorphism with ACE levels confirms the relationship across ethnic groups. The low frequency of the $D$ allele in Pima Indians shows that ethnic differences should be accounted for when studying the ACE gene.
\end{abstract}

(f Med Genet 1996;33:336-337)

Key words: angiotensin-I converting enzyme; insertion deletion polymorphism; ethnicity.

Diabetes and Thrombosis Research Group, Department of Clinical Medicine, University of Leeds, UK

C A Foy

L J McCormack

$\mathrm{J}$ H Barrett

A Catto

P J Grant

National Institute of Diabetes and Digestive and Kidney Diseases, Phoenix, Arizona, USA

W C Knowler

Correspondence to: Dr Foy, Diabetes and Thrombosis Research Group, Division of Medicine, G Floor Martin Wing, Leeds General Infirmary, Leeds LS1 3EX, UK.

Received

27 September 1995

Revised version accepted

for publication

for publication 16 November 1995
A polymorphic region of the angiotensin-I converting enzyme (ACE) gene has been related to plasma ACE levels. ${ }^{1}$ Detection of the polymorphism by PCR is based on the presence or absence of a $287 \mathrm{bp}$ sequence in intron $16 .^{2}$ Homozygotes for the deletion (DD) have levels of circulating ACE approaching twice that of those homozygous for the insertion (II). The DD genotype has been associated with an increased risk of coronary artery disease (CAD) and myocardial infarction (MI) in family and population based studies. ${ }^{34}$ However, other studies have failed to show this association, ${ }^{56}$ which may be because of differences in ascertainment of disease status or that the ACE genotype/phenotype interaction varies across ethnic groups. Pima Indians from Arizona, USA, have a low prevalence of heart disease compared to the total US population. ${ }^{78}$ The aim of this study was to determine the prevalence of the I/D polymorphism and its relationship to ACE levels in this population.

Pima Indians from Arizona, USA $(n=305)$ participating in continuing epidemiological studies (146 male, 159 female), median age 45 years (range 35-69), and a white comparison group ( $\mathrm{n}=80 ; 42$ male, 38 female), median age 48 years (range 20-70), were recruited. DNA was extracted and PCR performed to detect the $\mathrm{I} / \mathrm{D}$ polymorphism as previously described. ${ }^{29}$ Homozygous DD samples were typed with primers specific for the insertion to confirm genotype. ${ }^{10}$ Plasma samples were obtained from 300 of the Pima Indians and 73 of the white group, and ACE levels were determined by hydrolysis of furanacrylol-1phenylalanyl-glycylglycine (FAPGG) with subsequent decrease in absorbance at $340 \mathrm{~nm}$ being a measure of ACE activity. The coefficient of variation at $80 \mathrm{IU} / 1$ was $6 \%$ and at $250 \mathrm{IU} / 1$ was $3 \cdot 5-4 \%$. The figure shows amplification of samples with the I/D primers. Using the insertion specific primers one Pima subject was recategorised as an I/D. Table 1 shows the I/D genotyping results obtained, which were in Hardy-Weinberg equilibrium.

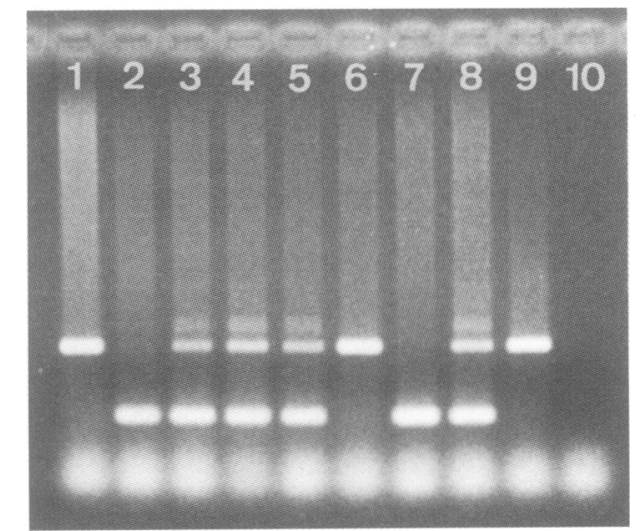

Amplification of the I/D polymorphism. Lanes 1, 6, and 9 II homozygotes, lanes 2 and 7 DD homozygotes, lanes 3-5 and 8 ID homozygotes, lane 10 blank control.

Table 1 Prevalence of the ACE I/D genotype in Pima Indians and whites

\begin{tabular}{lll}
\hline ACE genotype & Pima Indians & Whites \\
\hline II & $155(50 \cdot 8 \%)$ & $19(23 \cdot 8 \%)$ \\
ID & $125(41 \cdot 0 \%)$ & $39(48 \cdot 8 \%)$ \\
DD & $25(8 \cdot 2 \%)$ & $22(27 \cdot 5 \%)$ \\
Total & 305 & 80 \\
\hline
\end{tabular}


Table 2 Mean plasma ACE levels (standard deviations) according to $A C E I / D$ genotype

\begin{tabular}{lrl}
\hline ACE genotype & Pima Indians & Whites \\
\hline II & $74 \cdot 5(31 \cdot 7) \mathrm{n}=153$ & $58 \cdot 7(21 \cdot 1) \mathrm{n}=16$ \\
ID & $90 \cdot 2(39 \cdot 5) \mathrm{n}=124$ & $81 \cdot 9(29 \cdot 3) \mathrm{n}=35$ \\
DD & $103 \cdot 7(46 \cdot 6) \mathrm{n}=23$ & $94 \cdot 6(29 \cdot 6) \mathrm{n}=22$ \\
\hline
\end{tabular}

The frequency of the $\mathrm{D}$ allele was lower in Pimas than whites, frequencies $(95 \%$ confidence intervals) $0.29(0.25,0.32)$ and 0.52 $(0.44,0.60)$ respectively. The frequency of the $\mathrm{D}$ allele in the white group was similar to reported frequencies for other white populations. ${ }^{4}$ Table 2 shows mean plasma ACE levels according to I/D genotype. Univariate analysis showed no evidence of a relationship between ACE levels and age or sex in either population $(p>0 \cdot 1)$. ACE levels were strongly associated with genotype $(p=0.0001)$, and after allowing for genotype there was evidence of higher ACE levels in the Pima Indians than the white group $(p=0.03)$. The variation in ACE levels explained by the ACE polymorphism was $6.5 \%$ in the Pima Indians and $18 \%$ in the whites.

The results of the present study show that the $\mathrm{D}$ allele has a significantly lower frequency in Pima Indians than in whites. Previous studies have shown a lower frequency of the $\mathrm{D}$ allele in several non-European populations including Japanese, Chinese, Samoans, and Yanomami Indians. ${ }^{11-13}$ In all groups, a strong relationship existed between the I/D genotype and circulating ACE levels, as previously observed in white populations. Future studies of the ACE gene and vascular disease would take into ac- count the ethnic origin of the patients under study.

We thank the members of the Gila River Indian Community, Arizona for participating in the study and D Nagi for providing the Pima Indian samples. This work was supported by a grant the Pima Indian samples. This work was sup

1 Rigat B, Hubert C, Alhenc-Gelas F, Cambien F, Corvol P, Soubrier F. An insertion/deletion polymorphism in the angiotensin I-converting enzyme gene accounting for half the variance of serum enzyme levels. $\mathcal{f}$ Clin Invest 1990 86:1343-6.

2 Rigat B, Hubert C, Corvol P, Soubrier F. PCR insertion deletion polymorphism of the human angiotensin converting enzyme gene (DCP1)(dipeptidyl carboxypeptidase). Nucleic Acids Res 1992;20:1433.

3 Tiret L, Kee F, Poirier O, et al. Deletion polymorphism in angiotensin-converting enzyme gene associated with parental history of myocardial infarction. Lancet 1993; 341:991-2.

4 Cambien F, Poirier O, Lecerf $\mathrm{L}$, et al. Deletion polymorphism in the gene for angiotensin-converting enzyme is a potent risk factor for myocardial infarction. Nature

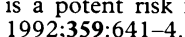

5 Lindpaintner K, Pfeffer M, Kreutz R, et al. A prospective evaluation of an angiotensin-converting enzyme gene polymorphism and the risk of ischemic heart disease. $N$ Engl f Med 1995;332:706-11.

6 Friedl W, Krempler F, Paulweber B, Pichler M, Sandhofer F. A deletion polymorphism in the angiotensin converting enzyme gene is not associated with coronary heart disease in an Austrian population. Atherosclerosis 1995;112:13743.

7 Nelson RG, Sievers ML, Knowler WC, et al. Low incidence of fatal coronary heart disease in Pima Indians despite high prevalence of non-insulin-dependent diabetes. Circulation 1990;81:987-95.

8 Ingelfinger J, Bennett P, Liebow I, Miller M. Coronary heart disease in the Pima Indians: electrocardiographic findings and postmortem evidence of myocardial infarction in and postmortem evidence of myocardial infarction in a
population with a high prevalence of diabetes mellitus.

9 Mansfield M, Stickland M, Carter A, Grant PJ. Polymorphisms of the plasminogen activator inhibitor-1 gene in type 1 and type 2 diabetes, and in patients with diabetic retinopathy. Thromb Haemostas 1994;71:1-3.

10 Shanmugam V, Sell K, Saha B. Mistyping ACE het erozygotes. PCR Meths Apps 1993;3:120-1.

11 Ishigami $\mathrm{T}$, Iwamoto $\mathrm{T}$, Tamura $\mathrm{K}$, et al. Angiotensin I converting enzyme (ACE) gene polymorphism and essential hypertension in Japan. Ethnic difference of ACE genotype. Am f Hypertens 1995;8:95-7.

12 Lee EJ. Population genetics of the angiotensin-converting enzyme in Chinese. Br f Clin Pharmacol 1994;37:212-14.

13 Barley J, Blackwood A, Carter ND, et al. Angiotensin converting enzyme insertion/deletion polymorphism: association with ethnic origin. $\mathcal{f}$ Hypertens $1994 ; 12: 955-7$. 